\title{
Groupthink Antecedent Conditions of the Social Media Team of the Ministry of Finance of the Republic of Indonesia
}

\author{
Aditya Arifiyanto; Prahastiwi Utari; Andre Noevi Rahmanto \\ Faculty of Social Science and Political Science, Communication Major Postgraduate Program of Eleven March University, \\ Central Java, Indonesia
}

https://doi.org/10.47814/ijssrr.v4i1.70

\begin{abstract}
The use of information technology to communicate has become a new culture in recent years, one of which is the use of social media in communication. No exception government agencies also use to disseminate government policy information. At the Ministry of Finance of the Republic of Indonesia, there is a team that specializes in managing the Ministry of Finance's social media accounts. Through this research will reveal whether the social media team of the Ministry of Finance of the Republic of Indonesia has the potential to indicate groupthink in the process of group communication in order to make effective decisions. This study will use Antecedent Conditions as a guideline for the main indicators. This study uses a descriptive qualitative method with semi-structured interviews as a way to retrieve data. Informants involved in this study were five people consisting of members of the Ministry of Finance's social media team from the January 2017 to December 2018 period. The results revealed that the Ministry of Finance social media team had the potential to Groupthink, this was known from group cohesion, organizational structure faults and external pressures that affect them at work.
\end{abstract}

Keyword: Group Communication; Netizens; Cohesiveness

\section{Introduction}

The development of information technology today has influenced communication behavior in the world (Williamson, K. et. al. 2008). The ease in interacting between humans makes the boundaries of communication disappear. We can communicate with anyone anywhere without any place or time barriers, this creates a new culture in social life in communicating digitally. Along with this cultural change, making every level of society, organization, company begin to utilize the use of digital technology to communicate, including government agencies.

Like organizations or companies, government agencies have a special part to do the task of establishing relationships with the community, which we are familiar with Public Relations (PR). But government PR has a different purpose than private organizations and companies, $\mathrm{PR}$ in the government is more aimed at providing education through the publication of government policies (Gelders, D., \& Ihlen, Ø. 2010). This was also carried out by the Public Relations Ministry of Finance of the Republic of Indonesia 
(MoF RI) to publish state financial policies to the public. At the Ministry of Finance, public relations activities are carried out by the Communication and Information Services Bureau (CIS Bureau).

Inside the CIS Bureau there is a section that has a special task of carrying out publications in communication through digital technology, using social media. They are usually called the MoF RI of social media team and they are responsible for the social media account @ KemenkeuRI. Organizationally the social media team does not have an official structure, but those who are members of the social media team have the task of being strategic planners in digital communication, social media admins and content creators.

Social media has patterns and can form differences in communication behavioral trends compared with direct communication patterns. Therefore, in planning digital communication strategies, the @ KemenkeuRI social media team needs to pay attention to the patterns of digital trends (Kurniasih, 2017). Speed is one of the factors to be considered in making digital content, this is needed so that people get accurate information related to state financial policies from their direct news sources, not through the mainstream media (Purworini, 2017).

To manage large accounts with crucial issues like this and by combining the characteristics of digital communication as above, the @KemenkeuRI social media team requires a condition that can facilitate communication in groups by producing effective outputs. Group cohesiveness is one of the factors that can influence the decision making process quickly and effectively. If the group is compact, the possibility of a debate in the discussion to formulate a digital communication strategy will be easy, because they will mutually believe that the group's decision will be the best decision because it is decided by the best people too, team cohesiveness can also cause a decision taken to be an incomplete decision due to the absence of high criticality in the team (Listi, 2013).

This feeling of mutual trust can arise if each team member is a person who truly masters and is an expert in digital communication, especially on social media. They are always up to date in knowing digital trends that are liked or disliked by netizens. In this condition, the Ministry of Finance as one of the government institutions has a bureaucratic organizational structure, where every employee who works is bound by bureaucratic work placement. Employees cannot easily choose the jobs they like and each leader in each section cannot easily choose the employees they like or want. This will provide a challenge in managing the @KemenkeuRI social media team if the members are not experts in the field of digital communication, or at least the members of the social media team have digital literacy skills above the average of other employees (Schmidt-Hertha \& Root. 2014).

In addition to the two factors above, what makes it easier in the process of making decisions quickly and effectively in group communication is a condition that can provoke their performance. This condition is one of them is the pressure from inside or outside the group. With this pressure, a group will have motivation in working, maybe this is caused by a negative sense of concern over the pressure so they want to prove that with the pressure the team will actually be able to make decisions that have a high likelihood of success.

In group communication, there is a theory that studies how a compact group communication process will produce a decision that is fast and effective, the theory is also called Groupthink. This theory was first put forward by Irving Janis in his book "Victims of Groupthink" (1972), Janis used the term Groupthink to describe a model of thinking of groups of people who had a cohesive nature. He defines Groupthink as a method of thinking applied by people when they are deeply involved in a cohesive group, if members want 
to achieve unamity thereby eliminating their motivation to realistically assess other alternative action sequences.

\section{Antecedent Conditions}

2. Observable Consequences, and

3. Groupthink Problem Solving.

Much research on Groupthink is done by communication scientists, but not much research uses Groupthink theory to examine a group that deals in the field of digital communication. Therefore, the author wants to provide a new perspective on the theory of Groupthink when it is examined in the communication of a group in a Government institution that works by using social media as a media for public relations activities.

\section{Problem Statement and Objective}

Through the explanation above, this research will focus on the acquisition of whether the @ KemenkeuRI social media team has a tendency to become a group that is indicated by Groupthink. This research will seek this answer by examining how the Antecedent Conditions on the social media team @ Ministry of Finance. In accordance with the theory of Groupthink from Janis, Antecedent Conditions are divided into three main indicators, which consist of cohesiveness, structural errors and provocative situations. Through this indicator the researcher will reveal whether there is a possibility of Groupthink occurring on the @ KemenkeuRI social media team.

\section{Literature Review}

\section{Group Communication}

A group is a group of people who have a common goal that interacts with each other to achieve a common goal, get to know each other, and view them as part of the group (Mulyana, 2005). Group communication is communication that takes place between several people in a "small" group such as in meetings, meetings, conferences and so on (Arifin, 1984). Michael Burgoon (in Wiryanto, 2005) defines group communication as face-to-face interaction between three or more people, with known goals, such as sharing information, protecting themselves, solving problems, where members can remember the personal characteristics of members the other precisely.

Both definitions of group communication above have security, that is, there is face-to-face communication, communication members consist of at least two or more people, and have specific work plan arrangements in achieving group goals. In line with Burgoon, B. Curtis, James J. Floyd, and Jerril L. Winsor (2005) revealed that group communication is established when three or more people face to face, normally a leader conducts supervision to achieve common goals or goals and can influence one with other. 


\section{Antecedent Conditions of Groupthink}

Groupthink is one of the theories for examining communication at the group level. This theory focuses on how a group works in effective decision making. This theory was put forward by Irving Janis in his book "Victims of Groupthink" (1972). Also in Paul't Hart's article, entitled "Irving L. Janis' Victims of Groupthink" (1991), here Hart reiterates that Janis uses the term Groupthink to explain a model of thinking of groups of people who have a cohesive nature.

He defines Groupthink as a method of thinking applied by people when they are deeply involved in a cohesive group, if members want to achieve unamity thereby eliminating their motivation to realistically assess other alternative action sequences. It can also be said that Groupthink is a way for groups to hold deliberations that minimize conflict and emphasize the need for unanimity.

Meanwhile, according to Beebe and Masterson (2015), Groupthink is an illusion of agreement, namely the type of thinking that arises when groups try to reduce conflict, increase cohesiveness, and reach consensus without considering, analyzing, and evaluating it.

In Janis's first article published on group communication and psychology under the title Groupthink in 1971, he mentioned the initial assumptions of the Groupthink theory, the first assumption was cohesiveness, which is the condition of groups that prioritize high cohesiveness. The stronger the level of cohesiveness of the group, the higher their sense of cohesiveness, eventually there was a close relationship between group members. Cohesiveness is one of the behaviors that shape the climate of group performance. Cohesiveness is explained as to how far group members are willing to work together to work together. The high group cohesiveness can be positive as a means to unite the group and can open their interpersonal relationships.

Second, there are structural errors such as isolation, inadequate advice, poor decision-making procedures, and closed minds in groups. Specific structural characteristics ("mistakes") in the organizational context in which the group works. In several articles mentioning various variations of structured errors, there are those that mention structural errors lies in organizational mistakes in placing people who are not in accordance with their expertise, forcing one's potential into work that he does not master.

The third assumption is a provocative situation, which is a condition in which there is confusion among members in expressing their opinions, because there is external pressure that can cause anxiety and fear due to the risk of failure. Under these conditions, the potential for Groupthink can increase sharply when decision makers are under pressure, especially when dealing with a crisis situation. In such circumstances, decision makers may feel a threat to their self-esteem because of the enormous burden of having to decide on impenetrable and complicated moral issues.

\section{Method}

This research uses a descriptive qualitative research approach, using semi-structured interviews to get the data. In qualitative research, the methods usually used are interviews, observation, and document utilization (Moleong, 2006). Interviews were conducted with the@KemenkeuRI social media team that worked in the period of January 2017 - December 2018, with a total of 5 informants. To facilitate the presentation of the data, the informants will be presented in the following table. 
Table 1: List of Informants

\begin{tabular}{|l|l|l|}
\hline \multicolumn{1}{|c|}{ Name } & \multicolumn{1}{|c|}{ Position } & \multicolumn{1}{c|}{ Educational Background } \\
\hline Rezha Sahhilny Amran (A1) & Team Leader & Undergraduate of Architectural Engineering \\
\hline Dewi Rusmayanti (A2) & Social Media Administrator & $\begin{array}{l}\text { of Architectural Engineering Visual } \\
\text { Communication Design }\end{array}$ \\
\hline Iin Kurniati (A3) & Social Media Administrator & $\begin{array}{l}\text { of Architectural } \\
\text { Communication Science }\end{array}$ \\
\hline Tubagus Prihastomo (A4) & Content Creator & Diploma 1 (PKN STAN) \\
\hline Ferry Irwandi (A5) & $\begin{array}{l}\text { Social Media Administrator } \\
\text { / Content Creator }\end{array}$ & Diploma 3 (PKN STAN) \\
\hline
\end{tabular}

The data analysis is done by systematically arranging interview guidelines then formulating it descriptively. Sugiyono (2005) states that the descriptive method is a method used to describe or analyze a research result but is not used to make broader conclusions.

\section{Result and Discussion}

As stated earlier, this study will use three indicators from Antecedent Conditions as a guide. These indicators include group cohesiveness, group structure errors and provocative situations.

\section{Group Cohesiveness Occurs Because of the Existence of Common Vision and Mission}

To obtain data related to what kind of cohesiveness occurs in the social media team @ Ministry of Finance, the researcher asked the informant with the question "do you think the social media team in your period was a compact team? Then what do you think makes your team cohesive? ". Through this question, researchers get the results that according to all informants, their group is a compact group because they feel that in making decisions for digital communication strategies it is always easy and there is no conflict if there are differences in discussion. This condition was first expressed by A1 informant as manager of social media accounts @KemenkeuRI, he felt he was at work,

"I have a vision that they can accept, I bring something into the team and they can accept that goal. People will have more enthusiasm in doing something if they have the same goal, in other words it is like emphasizing to them that we have the same enemy. "(informant A1)

Then we check the statement with informants who are members of other social media teams. The results also show a compatibility with the statement from A1 informants, that in their work, they feel they have the same goal, this makes it easier to make decisions in discussions.

"We are a compact team, because in determining decisions we can all be free to express opinions, issue each other's views and, most importantly, decisions can be taken right away" (informant A2)

"So to make good collective decisions we need a mutual agreement, our goals must be the same, such as when choosing to plant chillies in the \#SadarAPBN campaign or when determining content for the debt issue, how do we collectively find data that can represent the issue" (informant A3) 
"In making this design, I can say that I have a vision and mission with the team, where I often study what kind of design tends to be liked, I learn from it and then apply it in the design" (informant A4)

"In deciding on the use of 'Percaya' Film for Youtube content, we have the same vision and mission and consider the film to have the same potential impact, so we have no debate in deciding". (informant A5)

\section{Bureaucracy Policy in Determining Employee Formation Gives Impact to Structural Errors}

The next indicator is a structural faults. If it is related to the research theme of government institutions, structural faults can be found in the placement of resources in inappropriate job positions, where managing social media requires specific expertise and skills rather than daily office capabilities. Ministry of Finance employees have an interesting composition, which because of their affiliation with the State Finance Polytechnic - State Administrative College (PKN - STAN), makes the majority of graduates from PKN STAN work in the Ministry of Finance. In general, the education taught at PKN - STAN is a science of state financial administration, such as Accounting, Taxation and Customs and Excise. Not a few alumni from PKN - STAN are placed in the Ministry of Finance, this causes those in charge of the office who are sometimes unrelated to the discipline they had previously obtained.

A concrete example is that some PKN - STAN alumni are placed in the KLI Bureau, where the Bureau has the task and function of carrying out public relations activities in the Ministry of Finance. Even more so if they are placed to be a content creator for digital publications or to become Image Designers for print publications. This makes it a challenge for themselves and the organization, how they can work well even though they do not have public relations knowledge before.

A concrete example is that some PKN - STAN alumni are placed in the KLI Bureau, where the Bureau has the task and function of carrying out public relations activities in the Ministry of Finance. Even more so if they are placed to be a content creator for digital publications or to become Image Designers for print publications. This makes it a challenge for themselves and the organization, how they can work well even though they do not have public relations knowledge before. A concrete example is that some PKN STAN alumni are placed in the KLI Bureau, where the Bureau has the task and function of carrying out public relations activities in the Ministry of Finance. Even more so if they are placed to be a content creator for digital publications or to become Image Designers for print publications. This makes it a challenge for themselves and the organization, how they can work well even though they do not have public relations knowledge before.

With this, according to the author will be a new problem in conducting communication when discussing to make digital communication strategy planning decisions by the social media team @ Ministry of Finance, where the leader and team members will get input opinions from people who do not have expertise in digital communication.

\section{The Greatest Pressure felt by the @ KemenkeuRI Social Medical Team Derived from Netizens}

The last part of the Antecedent Conditions of Groupthink is a provocative situation. This conditions are defined where the group gets pressure from internal or external groups. This pressure can result in group anxiety or hesitation to argue for group decision making. In Groupthink theory such conditions can have a sharp chance of causing the group to fail in making effective decisions, moreover the pressure obtained is obtained in conditions of crisis within the group. 
To obtain this data, researchers conducted interviews with informants asking "what kind of pressures can influence the team in making a decision to formulate a digital communication strategy to the @KemenkeuRI social media account?". As a result, the informants agreed that the greatest pressure was obtained from outside the group, namely from netizens. But each informant described himself how netizens depressed them.

"If the pressure obtained from the leadership or peer I think there is no yes, if the pressure from outside is a lot, especially like the time of crisis, as in the reception of selection of prospective civil servants, there are many negative tones from the applicants to our Twitter, and I think we must act because if this issue is left unchecked it will roll and potentially affect the image of our institution in the eyes of netizens "( informant A1)

"The pressure that I feel is the pressure to get likes from netizens, so we are not like other ministries, we don't buy likes, we want those who like it to be really people" (informant A2)

"When I was a social media administrator, I positioned myself as a Minkeu (administrator of @ KemenkeuRI), when I was blasphemed as a Minkeu, I felt personally blasphemed. This can affect me in managing my social media account, on the other hand I feel hurt, on the other hand I keep introspection where there is a lack "( informant A3)

"When the team has formulated a strategy for content that has graphic design, I feel I have to make it as good as possible, when I make it not optimal, the impact reaches the social media right? If it's like that I feel depressed also, I feel like I'm thinking, so where exactly is my fault? Finally I feel insecured "( informant A4)

" The emphasis is more like how we are as a government account but can display something different and not stale in the eyes of the public, because of a different approach to corporate companies, because the mindset of the community feels that the ministry is an ancient organization that only plays old social media content" (informant A5)

\section{Conclusion}

Through data retrieval based on the Antecedent Conditions indicator above, it can be concluded that group communication that occurs in the @KemenkeuRI social media team can be said to be potentially indicated by Groupthink. It can be said like that because, to find out whether a group is potentially indicated Groupthink must show this initial indicator. In the first indicator of cohesiveness, the @ KemenkeuRI social media team can be said to be a compact group. The answers from the informants to this cohesiveness are relatively the same, which is related to the shared vision and mission of the team that affects their work.

As for the indicator of structural errors, revealed that as an organization that uses bureaucratic hierarchy, the placement of employees that are not in accordance with the specifications of the job needs becomes a problem in the decision making process. The final conclusion that can be drawn based on indicators of whether there is pressure at work reveals that netizens exert the greatest pressure felt by team members. When explored further, netizens are a part of a form of digital communication technology, where such pressures have not occurred in previous Groupthink research, moreover in studies that did not involve digital communication technology. 


\section{References}

Arifin, A. (1984). Strategi Komunikasi: Suatu Pengantar Ringkas. Bandung: Armico.

Beebe, S. A., \& Masterson, J. T. (2015). Communicating in small group: Principles and practices 11 th. Ed.

Curtis, Dan B., Floyd, James J., Winsor, Jerry L. (2005). Komunikasi Bisnis dan Profesional. Bandung: PT Remaja Rosdakarya.

Gelders, D., \& Ihlen, Ø. (2010). Government communication about potential policies: Public relations, propaganda or both? Public Relations Review, 36(1), 59-62.

Janis, I. L. (2008). Groupthink. IEEE Engineering Management Review, 36(1), 36.

Kurniasih, N. (2017). Optimalisasi Penggunaan Media Sosial untuk Perpustakaan.

Moleong, L. J. (2007). Metodologi Penelitian Kualitatif. Bandung: PT Remaja Rosdakarya Offset.

Mulyana, D. (2005). Ilmu Komunikasi: Suatu Pengantar. Bandung: PT Remaja Rosdakarya.

Purworini, D. (2017). Model informasi publik di era media sosial: Kajian grounded teori di pemda sukoharjo. Komuniti: Jurnal Komunikasi dan Teknologi Informasi, 6(1), pp. 3-14.

Schmidt, H., \& Root. (2014). Developig Media Competence and Work-Related Informational Behavior in Academic Studies. EduRe Journal, pp. 90-108.

Williamson, K., Bernath, V., Wright, S., \& Sullivan, J. (2008). Research students in the electronic age: Impacts of changing information behavior on information literacy needs. Communications in Information Literacy, 1(2), 4.

Wiryanto. (2005). Pengantar Ilmu Komunikasi. Jakarta: Gramedia Widiasarana Indonesia.

\section{Copyrights}

Copyright for this article is retained by the author(s), with first publication rights granted to the journal.

This is an open-access article distributed under the terms and conditions of the Creative Commons Attribution license (http://creativecommons.org/licenses/by/4.0/). 